much attention. With his interpretation of them, he significantly contributed to the deepening and expansion of stylistic analysis, which has now become the main basis of any classical archaeological research both in Germany and abroad.

\title{
References:
}

1. Zhebelev, S. A. (1923). Vvedenie v arkheologiyu. Chast' I. Istoriya arkheologicheskogo znaniya [Introduction to archeology. Part I. History of archaeological knowledge]. Petrograd : Nauka i shkola, pp.79-80.

2. Zhebelev, S. A. (1907). Adol'f Furtvengler. Nekrolog [Adolf Furtwängler. Necrologue]. Zhurnal ministerstva narodnogo prosveshcheniya [Ministry of Education Magazine].

\section{HISTORIOGRAPHIC MATERIALS FROM THE RESEARCH OF PYSANKARSTVO IN POLTAVA REGION}

\section{Viktor Tkachenko ${ }^{1}$}

DOI: https://doi.org/10.30525/978-9934-588-11-2_35

Pysankarstvo, as a component of traditional culture, at the end of the XIX beginning of the XX centuries existed throughout the territory of Ukraine, and the study of archival documents on this topic allows us to more fully disclose its development in the 20s of XX century in Poltava region. After all, the 20-30s of the twentieth century are characterized by a negative attitude of the Soviet authorities to religion and folk rites, customs and beliefs in general.

An unusual belief was recorded by P. Kovbasiuk in Poltava region. It concerns the conduct of the peasant economy. Namely, what needs to be done at Easter so that cattle are kept. After all, family welfare depended mainly on the state of the economy [1, ark. 54]. In his notes we find rare words of the Easter greeting poem, which was voiced by the Chumaks (salt traders) when they went to the houses to chrystosuvatysia (exchange a triple kiss as an Easter greeting ) [2, ark. 13 st.-14].

The celebration of Radonitsa and the use of red Easter eggs are mentioned in the message of M. Belokon from the farmstead of Sypatino of Malo-Pereschepynsky district of Poltava region [7, ark. 265].

From the collected and sent materials to the Ethnographic Commission by Cowba Michael from the village of Aleksandrivka in Poltava region we also see the facts of the existence of pysankarstvo in the village. In the entries of 1929 to the national calendar, the author, telling about the celebration of Easter, drew and sent some samples of eggs that existed in the village. It is noted that the little boys went from home to home on Easter and congratulated versely on the holiday, as well as played with Easter eggs [8, ark. 178-178].

\footnotetext{
${ }^{1}$ Research Fellow of the National Historical and Ethnographic Reserve «Pereiaslav», Ukraine 
In his answers to the folk calendar, I. Voloshenko writes that Easter bread (pasky), eggs, etc. are blessed. Easter eggs are painted with the paint which people buy, and the shells are dug into the ground «so that the blind man does not destroy the potatoes» $[8$, ark. $55 \mathrm{zv}-56]$. The correspondent also tells about children's games with Easter eggs «v katka» and «bytky». Among the materials of the storage unit 312 there is a black-and-white image of two Easter eggs. They were sent to the ethnographic commission by A. Tretin in 1928 from Globino of Kremenchug district. The author noted that the ornaments on them are called «crosses» and «belt». On both of them there are inscriptions «X. B.» (Christ is Resurrected). One figure really shows the cross [8, ark. 111].

The materials of S. Strilchenko from Kremenchuk region point out that at Easter children played «v bytky», young children went to the houses to exchange a triple kiss as an Easter greeting and at the same time told poems [3, ark. 33-34]. The author also covers the process of coloring Easter eggs and making Easter eggs, noting that for this purpose onion peels, branches of poplar, maple and other plants were used [3, ark. 47]. S. Strilchenko also did not ignore the church rite of taking out the Shroud on Friday before Easter, indicating that the church was attended by many people and when kissing the Shroud the priest was given eggs. The correspondent also noted such a moment: as someone collected a lot of eggs, the women usually crumbled and dried them finely, and then threw them into the soup so that they would not go bad. There were such people, as the author writes, who sold them in cities at the market [3, ark. 36]. On Radonitsa, as indicated in the note, «three loaves and a dozen eggs» were taken for the priest [3, ark. 43].

In the materials from Poltava we find the belief that «on Maundy Thursday you can't paint eggs... and boil them», because «chickens will squeak» [4, ark. 38], and the blessed egg should be thrown into the water for the drowned people [4, ark. 39]. Information about the beliefs associated with eggs, what dishes were taken for the blessing, as well as the celebration of Easter, the division of the blessed dishes between the cattle and Easter greetings are found in the records made by M. Khrapal in the village of Bobrovnik in Zenkovsky district [4, ark. 62], in the unit materials about the celebration of Easter in the village of Malaya Rudka are also stored [4, ark. 66]. The material from Zhuravka village written down by K. Kozubenko, a student of Poltava Institute of Public Education, is quite informative. The respondent notes that «on Friday and Saturday they paint eggs, bake kulichi» [4, ark. 75], «on Easter at dawn the guys go khristosuvaty, for what they are given eggs or candies and bagels, children play navbytky and in pokotyushky» [4, ark. 76]. The author also points out that «the night before the second day the guys go home» oblyvaty (to pour on). They go into houses where there are adult girls, and they are presented with Easter eggs and they go further. It is worth noting that K. Kozubenko points out that no one can explain this custom, what it means, and «now pouring is understood as simple rural begging» [4, ark. 76].

The records of students from Malo-Pereschepinska school in Poltava region contain information about the chrystosuvannia of children on Easter (the exchange of a triple kiss as an Easter greeting), the poems that sound at the same time, it is noted 
that for this they are given Easter eggs. It is indicated that both krashankas and pysankas were prepared for Easter [5, ark. 99-100]; samples of poems pronounced at the time of chrystosuvannia are also given in the material from the village of Kustanovo in Novosanzharsk region. The author Scriaga A.D. also notes that children play with Easter eggs «na vbytky» [5, ark. 103].

The custom and beliefs that it is necessary to wash in water with a consecrated red egg to be beautiful all age, was also in the village of Chernukhi [6, ark. 124-124].

One of the respondents recorded congratulatory poems (khlystivky), in the village of Kishinets, Dikan district of Poltava region. The author noted that guys up to 14 years old chrystosyiutsya (exchange a triple kiss as an Easter greeting ) on the first day of Easter [9]. As for the Easter verses and their notes, having analyzed the known materials, we can say that this phenomenon was obviously spread throughout Ukraine. After all, they are mentioned in the works of researchers of the Western Ukrainian culture under the name of ryndzivky. They existed in a slightly different form in Polissya.

Thus, it can be stated that pysankarstvo was quite common in Poltava region in the 20 s of the twentieth century. It preserved its original traditions in the common ritual traditions of the local inhabitants.

\section{References:}

1. Arkhivni naukovi fondy rukopysiv ta fonozapysiv IMFE im. M.T. Rylskoho NAN Ukrainy [Archival scientific foundations of manuscripts and phonograms M. Rilsky IASFE Ukrainian National Academy of Sciences]. F. 1. Unit 418. Ark. 54.

2. Arkhivni naukovi fondy rukopysiv ta fonozapysiv IMFE im. M.T. Rylskoho NAN Ukrainy [Archival scientific foundations of manuscripts and phonograms M. Rilsky IASFE Ukrainian National Academy of Sciences]. F. 1. Unit 419. Ark. 13 st. 14.

3. Arkhivni naukovi fondy rukopysiv ta fonozapysiv IMFE im. M.T. Rylskoho NAN Ukrainy [Archival scientific foundations of manuscripts and phonograms M. Rilsky IASFE Ukrainian National Academy of Sciences]. F. 1. Unit 443. 143 ark.

4. Arkhivni naukovi fondy rukopysiv ta fonozapysiv IMFE im. M.T. Rylskoho NAN Ukrainy [Archival scientific foundations of manuscripts and phonograms M. Rilsky IASFE Ukrainian National Academy of Sciences]. F. 1. Unit 620. Ark. 76.

5. Arkhivni naukovi fondy rukopysiv ta fonozapysiv IMFE im. M.T. Rylskoho NAN Ukrainy [Archival scientific foundations of manuscripts and phonograms M. Rilsky IASFE Ukrainian National Academy of Sciences]. F. 1. Unit 629. Ark. 103.

6. Arkhivni naukovi fondy rukopysiv ta fonozapysiv IMFE im. M.T. Rylskoho NAN Ukrainy [Archival scientific foundations of manuscripts and phonograms M. Rilsky IASFE Ukrainian National Academy of Sciences]. F. 1. Unit 636. Ark. 124-124.

7. Arkhivni naukovi fondy rukopysiv ta fonozapysiv IMFE im. M.T. Rylskoho NAN Ukrainy [Archival scientific foundations of manuscripts and phonograms M. Rilsky IASFE Ukrainian National Academy of Sciences]. F. 1-add. Unit 309. Ark. 265.

8. Arkhivni naukovi fondy rukopysiv ta fonozapysiv IMFE im. M.T. Rylskoho NAN Ukrainy [Archival scientific foundations of manuscripts and phonograms M. Rilsky IASFE Ukrainian National Academy of Sciences]. F. 1- add. Unit 312. 200 ark.

9. Arkhivni naukovi fondy rukopysiv ta fonozapysiv IMFE im. M.T. Rylskoho NAN Ukrainy [Archival scientific foundations of manuscripts and phonograms M. Rilsky IASFE Ukrainian National Academy of Sciences]. F. 1- add. Unit 512. 130 ark. 